\title{
Genetic differentiation and phylogenetic relationships among Greek Salmo trutta L. (brown trout) populations as revealed by RFLP analysis of PCR amplified mitochondrial DNA segments
}

\author{
A. P. APOSTOLIDIS, Y. KARAKOUSIS + \& C. TRIANTAPHYLLIDIS* \\ Department of Genetics, Development and Molecular Biology, School of Biology, Aristotle University of \\ Thessaloniki, GR-540 06 Thessaloniki, Macedonia, Greece
}

\begin{abstract}
The genetic differentiation and phylogenetic relationships of 13 populations (11 from Greece, one from Albania and one from France) of brown trout (Salmo trutta L.) were investigated at the mtDNA level. RFLP analysis of four segments of mitochondrial DNA (D-loop, cytochrome $b$ and ND-5/6) amplified by PCR was used. Seven of 14 restriction endonucleases were found to detect variability in the ND-5/6 regions, whereas four and two out of 17 and 16 were polymorphic in the D-loop and cytochrome b, respectively. Eleven different haplotypes were observed. The observed interpopulation diversity was very high (mean $=1.65$ per cent), whereas the intrapopulation diversity was low in most cases (mean $=0.063$ per cent). Five phylogenetic assemblages were identified. The results demonstrate that Greece is one of the regions where brown trout display very high levels of genetic diversity. Most populations were genetically very distinct, possessing private mtDNA genotypes. Therefore, they represent unique gene pools which may warrant individual recognition for conservation and management. The genetic relationships among populations suggested by mtDNA data were not in accordance with allozyme data. This study illustrates the importance of considering the historical biogeography of a species in order to understand its population genetic structure. It also reinforces the view that mtDNA analysis represents a powerful tool to study past and present demographic phenomena.
\end{abstract}

Keywords: genetic variation, Greece, mtDNA RFLP, phylogeny, Salmo trutta.

\section{Introduction}

For many years allozyme electrophoresis was the prevalent technique in the investigation of the differentiation of brown trout (S. trutta L.) native populations (reviewed in Ferguson, 1989). Collectively, analyses of allozyme variation have revealed that genetically brown trout is one of the most highly structured fish species with more than 55 per cent of the total genetic diversity distributed among populations in some regions (Krieg \& Guyomard, 1985; Apostolidis et al., 1996). Recent advances in

* Correspondence.

†This paper is dedicated to the memory of the late Dr Y. Karakousis by both his student (A.A.) and his professor (C.T.). molecular biology have provided the opportunity to apply new techniques to population genetic studies, either to investigate phylogenetic problems or to detect the degree of differentiation among brown trout populations. These techniques include mtDNA analysis, minisatellite single locus probes (Taggart \& Ferguson, 1990), multilocus fingerprinting (Prödohl et al., 1992) and microsatellites (Estoup et al., 1993).

The advantages of mitochondrial DNA as a tool for population genetics have been extensively reviewed (Avise, 1994). Earlier studies on brown trout mtDNA variation have included RFLP analysis on populations originating mainly from NorthWestern Europe (e.g. Gyllenstein \& Wilson, 1987; Hynes et al., 1989; Bembo et al., 1994; Hall \& Nawrocki, 1995) and in some cases they revealed 
considerable variation within and among brown trout populations. Furthermore, sequencing of D-loop and protein coding genes of mtDNA has also been used to clarify the phylogenetic relationships of brown trout populations from different European areas (Bernatchez et al., 1992; Giuffra et al., 1994).

To investigate the genetic differentiation and phylogenetic relationships among Greek brown trout populations at the mtDNA level, PCR was used. Specifically, D-loop, cytochrome $b$ and the ND-5/6 segments of mtDNA were amplified and subsequently screened for RFLPs. The populations under investigation had been previously analysed at the allozyme level as well (Karakousis \& Triantaphyllidis, 1990; Apostolidis et al., 1996).

\section{Materials and methods}

\section{Sample collections and mtDNA RFLP analysis}

Samples of brown trout were collected from 11 different Greek streams (Fig. 1). One more sample was obtained from the river Garonne (Pyrenees, France) and another sample from the lake Ohrid (Albania). The last sample is considered to belong to the subspecies $S$. $t$. letnica. All Greek brown trout populations belong to two different ichthyogeographical zones: south Adriatic-Ionian, which includes the rivers of western and south-western Greece and Ponto-Aegean (Venetikos, Tripotamos and Nestos rivers), which includes the rivers of northern and north-eastern Greece. The population of Nestos is the only known population in which stocking activities have taken place, approximately 20 years ago. In particular, 20000 fingerlings of Salmo trutta ssp. originating from a fish farm at Acheloos1, were released in 1976 and 1979 at the drainage of Nestos. The rest of the samples were obtained from unstocked populations although we cannot entirely rule out unrecorded introductions. Liver was removed from the specimens and kept in liquid nitrogen. DNA was extracted according to Bernatchez et al. (1988).

Mitochondrial DNA variation was analysed by restriction fragment length polymorphisms (RFLPs) performed on PCR-amplified products for 264 individuals. The primers used for mtDNA D-loop, cytochrome $b$ and ND-5/6 amplification were described by Bernatchez et al. (1992), Kocher et al. (1989) as modified by McVeigh et al. (1991), and Cronin et al. (1993), respectively. Double strand DNA was amplified in $50 \mu \mathrm{L}$ reaction volumes containing 2 units of
Taq polymerase, $5 \mu \mathrm{L}$ of $10 \times$ reaction buffer (200 mM $\left(\mathrm{NH}_{4}\right) \mathrm{SO}_{4}, 750 \mathrm{~mm}$ Tris- $\mathrm{HCl} \mathrm{pH} 9.0,0.1$ per cent (w/v) Tween), $2.5 \mathrm{~mm}$ (D-loop and cyt b) or $4.0 \mathrm{~mm}$ (ND-5/6) $\mathrm{MgCl}_{2}, 10 \mathrm{~mm}$ dNTPs, $30 \mathrm{pmol}$ (picomole) of each primer and approximately 50-100 ng of DNA. Additionally for the D-loop segment $1 \mu \mathrm{L}$ of $100 \mu \mathrm{g} \mathrm{mL}^{-1} \mathrm{BSA}$ was added.

PCR amplification conditions were as follows: one preliminary denaturation at $95^{\circ} \mathrm{C}(5 \mathrm{~min})$, followed by strand denaturation at $94^{\circ} \mathrm{C}(1 \mathrm{~min})$, annealing at $53^{\circ} \mathrm{C}(1 \mathrm{~min})$ and primer extension at $72^{\circ} \mathrm{C}(1.5$ min), repeated for 35 cycles and a final extension at $72^{\circ} \mathrm{C}(10 \mathrm{~min})$, for the segment of the D-loop. For cytochrome $\mathrm{b}$ the amplification programme was: $94^{\circ} \mathrm{C}(45 \mathrm{~s}), 52^{\circ} \mathrm{C}(45 \mathrm{~s}), 72^{\circ} \mathrm{C}(1 \mathrm{~min})$ and a final extension at $72^{\circ} \mathrm{C}(5 \mathrm{~min})$, and for ND $5 / 6$ it was: $95^{\circ} \mathrm{C}(1 \mathrm{~min}), 56^{\circ} \mathrm{C}(1 \mathrm{~min}), 72^{\circ} \mathrm{C}(2.5 \mathrm{~min})$ and a final extension at $72^{\circ} \mathrm{C}(10 \mathrm{~min})$, both for 30 cycles.

The amplified segments were subsequently screened for polymorphism with the following 14 restriction endonucleases: AluI, AseI, AvaII, Bam HI, BanI, EcoRI, HaeIII, HinfI (except cytochrome b), HpaII, MluI, NruI, PstI, SalI, Taq ${ }^{a}$ I. In addition for the cytochrome b and D-loop segments, three more enzymes were used: Bst UI, DdeI and XbaI. For each sample 5-10 $\mu \mathrm{L}$ of the PCR reaction containing amplified DNA was digested with the appropriate restriction enzyme. The digested samples were then electrophoretically separated on 2 per cent agarose gels in $1 \times$ TBE (Tris-borate-EDTA) buffer, stained with ethidium bromide, visualized under UV light and documented photographically. For the D-loop and cytochrome b segments, some of the digested fragments were also separated on 8 per cent polyacrylamide gels (PAGE).

\section{Data analysis}

Distinct single endonuclease patterns were identified by a specific letter in order of appearance (Tables 1 and 2). Each fish was assigned a multiletter code that described its composite mtDNA genotype (Table 3). The raw data were fragment profiles, but we inferred site differences among haplotypes from changes in fragment profiles as these could be accounted for by the gain or loss of particular restriction sites. For each enzyme a minimum path network of site differences among fragment profiles was constructed (Fig. 2). Both distance and character-based analyses were used to define genetic groups and phylogenetic relationships. Thus, the restriction site pattern data was analysed using the GENERATE, D and DA programs contained in the REAP package (McElroy et al., 1991), and the FITCH, 
MIX, BOOT and NEIGHBOUR programs contained in the PHYLIP 3.4 computer package (Felsenstein, 1992). The degree of geographical heterogeneity of mtDNA haplotype distributions was assessed using a $\chi^{2}$-statistic as described by Roff \& Bentzen (1989). The significance level was obtained by 10000 Monte Carlo randomizations using the MONTE program from the REAP package.

$N_{\text {ST }}$ (Lynch \& Crease, 1990) was used to estimate the degree of population subdivision at the nucleotide level. The resulting index gives the ratio of the average genetic distance between genes from different populations relative to that among genes in the population. Values of $N_{\mathrm{ST}}$ range from 0 (no population subdivision) to 1 (complete population subdivision). Distance matrices constructed from allozyme (Apostolidis et al., 1996) and mtDNA data (Table 4) were compared using a Mantel test (1967) incorporated in the NTSYS computer program (Rohlf, 1990).

\section{Results \\ Mitochondrial DNA diversity and phylogenetic differentiation}

The amplified segments of D-loop, cytochrome b and ND-5/6 had an approximate size of $1.15 \mathrm{~kb}, 360$ bp and $2.5 \mathrm{~kb}$, respectively. Eleven and four of the 17 and 16 restriction enzymes used to screen the 13 brown trout populations have a recognition site on the D-loop and cytochrome b segments, respectively, and eight of 14 restriction enzymes have a recognition site on the ND-5/6 segments. These enzymes were used for routine screening of populations in each segment and generated, in all of the amplified segments, a total of 70 restriction sites corresponding to an estimated 302 bp analysed. Fragment patterns generated by each enzyme and restriction site differences between genotypes inferred from these are presented in Tables 1 and 2 and Fig. 2, respectively. Polymorphism was found in all three

Table 1 Fragment size estimates (in base pairs) of all fragment patterns observed on mtDNA D-loop and cytochrome b segments, among 13 brown trout populations

\begin{tabular}{|c|c|c|c|c|c|c|c|c|c|c|c|c|c|c|c|c|}
\hline \multicolumn{17}{|c|}{ D-loop } \\
\hline Alu $\mathrm{I}$ & A & B & $\mathrm{C}$ & AseI & A & $\mathrm{B}$ & $\mathrm{C}$ & BanI & A & B & Bst $\mathrm{UI}$ & A & $D d e \mathrm{I}$ & A & Eco RI & A \\
\hline 590 & - & - & & 895 & & - & & 870 & - & - & 800 & - & 490 & - & 630 & A \\
\hline 550 & & - & - & 620 & - & & - & 200 & & - & 350 & - & 420 & - & 530 & - \\
\hline 500 & - & & & 275 & - & & & 180 & - & & & & 260 & - & & \\
\hline 340 & & & - & 185 & & & - & $* 20$ & - & & & & & & & \\
\hline 250 & & & - & 135 & - & - & - & & & & & & & & & \\
\hline 50 & - & & & $\begin{array}{l}90 \\
80\end{array}$ & -- & - & - & & & & & & & & & \\
\hline Hinf $\mathrm{I}$ & & & & $\operatorname{Taq}^{a} \mathbf{I}$ & & & & BamHI & & HaeIII & & HpaII & & & & \\
\hline & $\mathrm{A}$ & & & & A & & & & A & & A & & A & B & & \\
\hline 730 & - & & & 660 & - & & & 820 & - & 1080 & - & 590 & - & & & \\
\hline 300 & - & & & 470 & - & & & 310 & - & 70 & - & 340 & - & - & & \\
\hline 100 & - & & & & & & & & & & & 300 & & - & & \\
\hline & & & & & & & & & & & & 290 & & - & & \\
\hline & & & & & & & & & & & & 210 & - & - & & \\
\hline Cytoct & ne $b$ & & & & & & & & & & & & & & & \\
\hline AluI & & $D d e \mathrm{I}$ & & HaeIII & & & HpaII & & & & & & & & & \\
\hline & A & & A & & A & B & & A & $\mathrm{B}$ & & & & & & & \\
\hline $\begin{array}{l}210 \\
150\end{array}$ & - & 310 & - & 360 & - & & 290 & - & & & & & & & & \\
\hline 150 & - & 50 & - & 320 & & - & 190 & & - & & & & & & & \\
\hline & & & & $* 40$ & & - & $\begin{array}{r}100 \\
70\end{array}$ & - & - & & & & & & & \\
\hline
\end{tabular}

Fragments marked with asterisks were not observed but assumed under the criterion of minimum mutational steps involved in fragment changes. 
Table 2 Fragment size estimates (in base pairs) of all fragment patterns observed on mtDNA ND-5/6 segments, among 13 brown trout populations

\begin{tabular}{|c|c|c|c|c|c|c|c|c|c|c|c|c|c|c|c|c|c|}
\hline Alu $\mathrm{I}$ & & & & & & & AseI & & & & AvalI & & & & Hael & & \\
\hline & A & B & C & D & $\mathrm{E}$ & $\mathrm{F}$ & & A & B & $\mathrm{C}$ & & A & B & C & & A & B \\
\hline 1090 & & - & & & & & 1430 & - & - & - & 1700 & & - & - & 870 & - & \\
\hline 940 & - & & - & & & - & 1060 & & - & & 1490 & - & & & 710 & - & - \\
\hline 690 & & & & & - & & 580 & - & & & 810 & & & - & 580 & & - \\
\hline 590 & & & & - & & & 550 & & & - & 570 & - & - & & 570 & - & - \\
\hline 490 & - & - & - & - & - & - & 480 & - & & - & 240 & - & - & & 290 & & - \\
\hline 350 & & & & - & & & ${ }^{*} 30$ & & & - & 210 & - & & & 190 & & \\
\hline 280 & - & - & - & - & & & & & & & & & & & 170 & - & - \\
\hline 250 & - & - & - & - & - & - & & & & & & & & & 130 & - & - \\
\hline 250 & & & - & & - & & & & & & & & & & ${ }^{*} 60$ & - & - \\
\hline 230 & - & - & & - & - & - & & & & & & & & & & & \\
\hline 200 & & & & & - & - & & & & & & & & & & & \\
\hline 150 & - & & - & - & - & - & & & & & & & & & & & \\
\hline *100 & - & - & - & - & - & - & & & & & & & & & & & \\
\hline$* 80$ & & & & & - & - & & & & & & & & & & & \\
\hline${ }^{*} 20$ & - & - & & - & - & - & & & & & & & & & & & \\
\hline HinfI & & & & HpaII & & & & & $\operatorname{Ta} q^{a} I$ & & & & EcoRI & & & & \\
\hline & A & B & C & & A & B & C & D & & A & B & C & & A & & & \\
\hline 930 & & - & & 1090 & & - & - & - & 780 & - & & & 2250 & - & & & \\
\hline 810 & & & - & 760 & - & - & - & - & 640 & & - & & 250 & - & & & \\
\hline 580 & - & & & 570 & - & & & & 580 & - & - & - & & & & & \\
\hline 490 & - & & & 520 & - & & & & 550 & & & - & & & & & \\
\hline 430 & - & - & - & 320 & - & - & - & & 500 & - & & - & & & & & \\
\hline 290 & - & - & - & 290 & - & - & & - & 330 & & - & & & & & & \\
\hline 270 & - & - & - & 270 & & & & - & 310 & - & - & - & & & & & \\
\hline 260 & & & - & 160 & & & - & & 290 & - & - & - & & & & & \\
\hline 240 & - & - & - & 130 & & & - & & 230 & & & - & & & & & \\
\hline 180 & - & - & - & $* 50$ & & & & - & 170 & & - & & & & & & \\
\hline 140 & & - & & & & & & & 140 & & - & & & & & & \\
\hline
\end{tabular}

Fragments marked with asterisks were not observed but assumed under the criterion of minimum mutational steps involved in fragment changes.

segments. The restriction enzymes detecting variation in the D-loop, cytochrome $b$ and ND-5/6 segments are indicated in Tables 1 and 2. The 11 different haplotypes (composite genotypes) which were found in the populations examined and the haplotype frequencies of the sampled populations are given in Table 3. Pairwise sequence divergence estimates among the 11 haplotypes varied from 0.21 to 3.42 per cent. The number of observed haplotypes within populations ranged from one to three (Table 3). Among 11 detected genotypes, seven were private, i.e. observed in one population. Populations of Thyamis-Alfios and Acheloos2-Mornos shared a fixed mtDNA haplotype diversity, respectively.

The FITCH phenogram, resulting from the distance matrix among all mtDNA haplotypes using the unconstrained branch-length clustering method of
Fitch \& Margoliash (1967), is presented in Fig. 3. The overall Wagner parsimony analysis of site changes generated several equally parsimonious networks, each requiring a minimum of 19 site changes. The five clusters resolved in the distancebased analysis were supported in all of the parsimonious trees. Both the FITCH phenogram (Fig. 3) and the majority-rule consensus tree (Fig. 4) revealed four main haplotype clusters separated by mean sequence divergence estimates ranging from 2.39 to 3.40 per cent. Haplotype 10 (group I), found only in the Atlantic population, was used as an outgroup in order to access the phylogenetic relationships between Greek brown trout populations. Haplotype 11, found in the population of Voidomatis and in one individual from the population of Venetikos, comprised a second group (group II). 


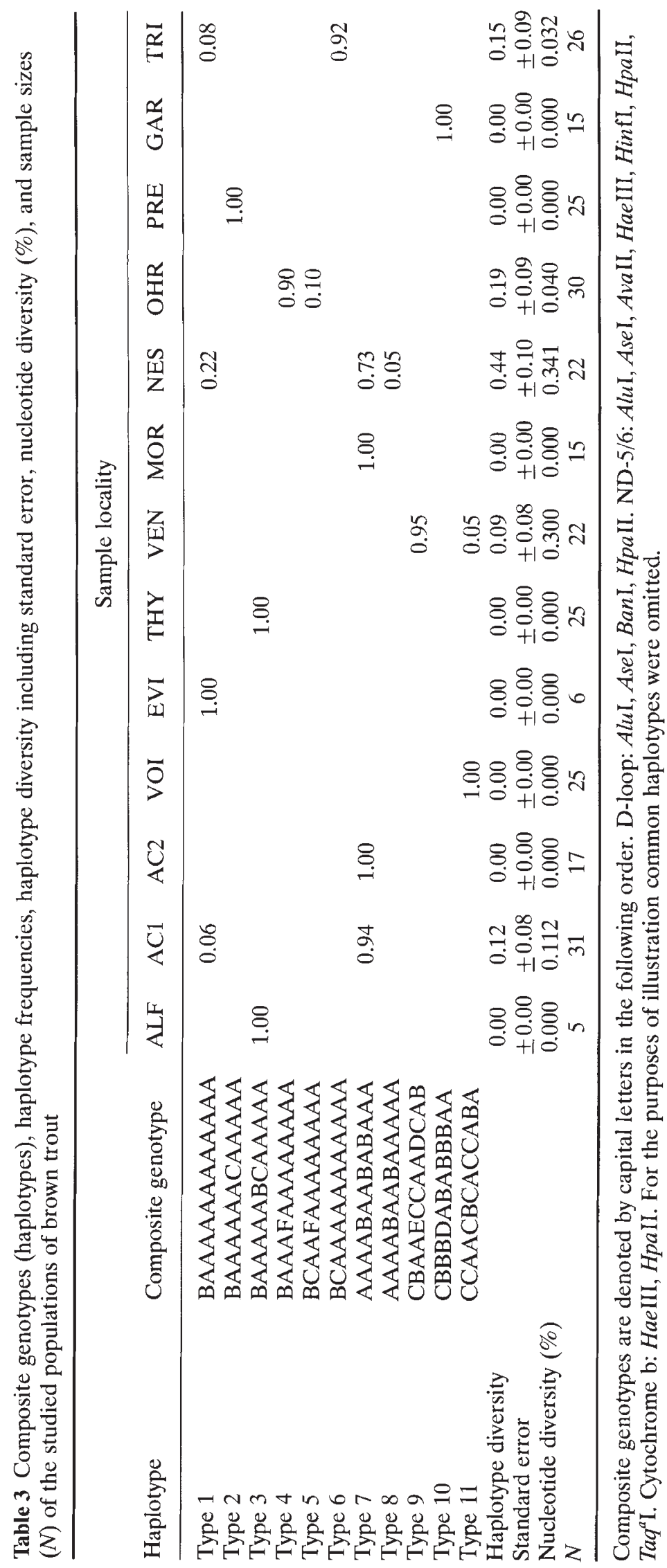

(c) The Genetical Society of Great Britain, Heredity, 77, 608-618. 
Table 4 Nucleotide divergence $\left(\times 10^{2}\right)$ for mtDNA PCR-RFLP analysis (below main diagonal), and pairwise estimates of Nei's standard genetic distance for allozymes (above main diagonal) among the 13 brown trout populations

\begin{tabular}{lccccccccccccc}
\hline Pop. & AC1 & AC2 & ALF & EVI & GAR & MOR & NES & OHR & PRE & THY & TRI & VEN & VOI \\
\hline AC1 & & \multirow{2}{*}{0.004} & 0.079 & 0.005 & 0.145 & 0.021 & 0.064 & 0.078 & 0.105 & 0.032 & 0.092 & 0.061 & 0.037 \\
AC2 & 0.002 & & 0.069 & 0.010 & 0.119 & 0.008 & 0.057 & 0.054 & 0.112 & 0.013 & 0.070 & 0.046 & 0.039 \\
ALF & 1.285 & 1.401 & & 0.080 & 0.109 & 0.075 & 0.049 & 0.018 & 0.101 & 0.083 & 0.052 & 0.034 & 0.040 \\
EVI & 0.784 & 0.898 & 0.473 & & 0.146 & 0.016 & 0.048 & 0.078 & 0.096 & 0.036 & 0.074 & 0.055 & 0.038 \\
GAR & 2.980 & 3.069 & 2.628 & 2.577 & & 0.109 & 0.091 & 0.070 & 0.176 & 0.108 & 0.076 & 0.067 & 0.106 \\
MOR & 0.002 & 0.000 & 1.401 & 0.898 & 3.068 & & 0.047 & 0.046 & 0.122 & 0.006 & 0.047 & 0.039 & 0.056 \\
NES & 0.018 & 0.044 & 1.009 & 0.513 & 2.796 & 0.044 & & 0.035 & 0.054 & 0.070 & 0.015 & 0.012 & 0.026 \\
OHR & 1.006 & 1.120 & 0.695 & 0.220 & 2.794 & 1.120 & 0.734 & & 0.108 & 0.045 & 0.019 & 0.010 & 0.043 \\
PRE & 1.025 & 1.140 & 0.251 & 0.222 & 2.847 & 1.140 & 0.750 & 0.444 & & 0.152 & 0.094 & 0.076 & 0.060 \\
THY & 1.285 & 1.401 & 0.000 & 0.473 & 2.628 & 1.401 & 1.009 & 0.695 & 0.251 & & 0.061 & 0.049 & 0.074 \\
TRI & 0.963 & 1.076 & 0.660 & 0.189 & 2.749 & 1.076 & 0.694 & 0.363 & 0.410 & 0.660 & & 0.007 & 0.047 \\
VEN & 2.853 & 2.940 & 2.417 & 2.466 & 3.110 & 2.940 & 2.672 & 2.234 & 2.727 & 2.417 & 2.625 & & 0.021 \\
VOI & 3.112 & 3.200 & 2.660 & 2.708 & 3.386 & 3.200 & 2.928 & 2.877 & 2.980 & 2.660 & 2.436 & 2.997 & \\
\hline
\end{tabular}

Fig. 1 Brown trout sampling sites: NES, Nestos; TRI, Tripotamos; PRE, Ag. Germanos (Prespa); OHR, Ohrid; VEN, Venetikos; VOI, Voidomatis; THY, Thyamis; AC1, Acheloos1; AC2, Acheloos2; EVI, Evinos; MOR, Mornos; ALF, Alfios. The population of Garonne (Pyrenees-France) is not indicated.

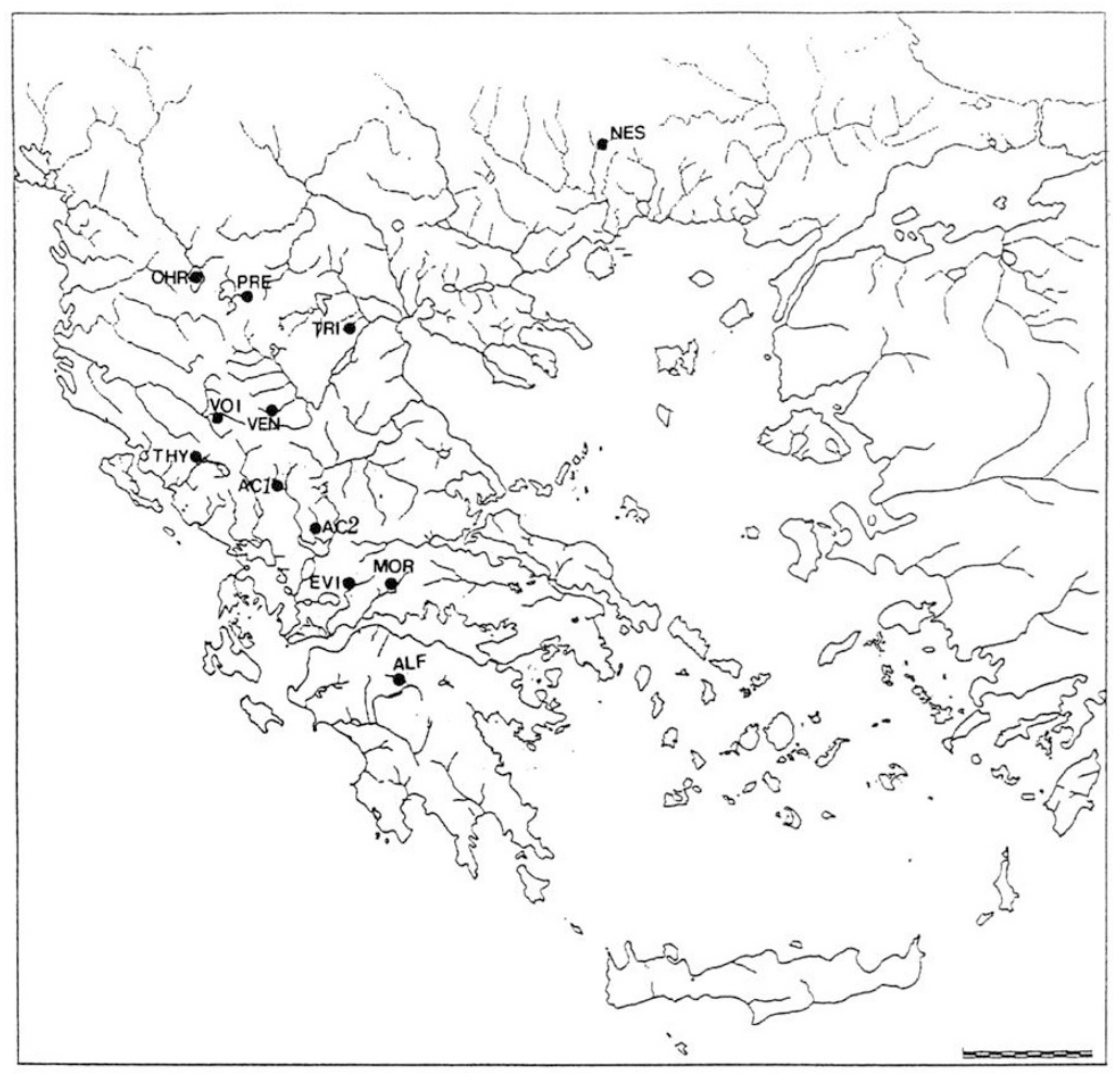

The third group (III), consisted of haplotype 9 found only in the population of Venetikos. The IV group comprises all the rest haplotypes and was supported in 80 per cent of the bootstrap estimates. However, within group IV haplotypes 7 and 8, supported at the 89 per cent level in the majority- rule consensus tree, consist of an internal group $\mathrm{IV}^{\mathrm{A}}$ separated by 0.68 per cent sequence divergence from its clonal IV group. These haplotypes were found in populations of Acheloos1 and 2, Mornos and Nestos. The lineages show little distinct geographical structure with haplotypes from group IV found in 


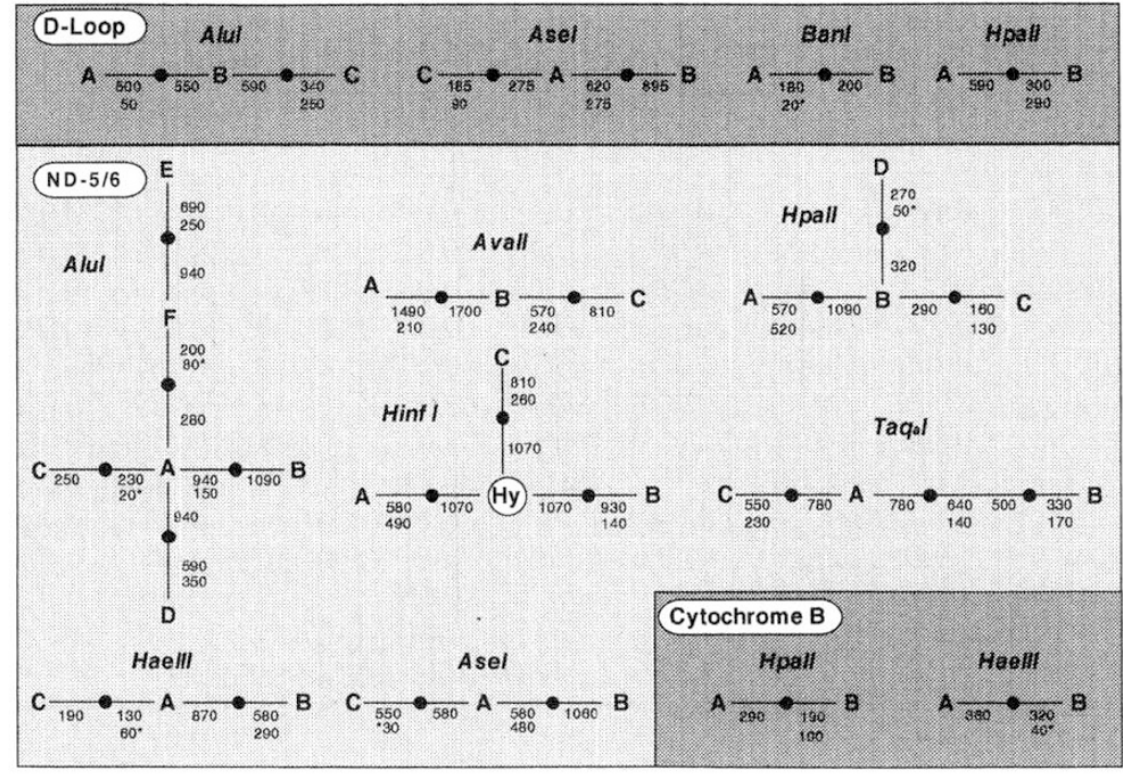

Fig. 2 Parsimonius, unrooted networks illustrating relationships among fragment patterns observed for all polymorphic restriction enzymes described in Tables 1 and 2. Site changes were parsimoniously deduced from observed changes in the banding pattern. The fragment sizes involved in differences among patterns are given alongside the branches. Several fragments, identified by asterisks, were not observed but assumed under the criterion of minimizing mutational steps between restriction morphs. (Hy refers to hypothetical haplotype not observed in the study).

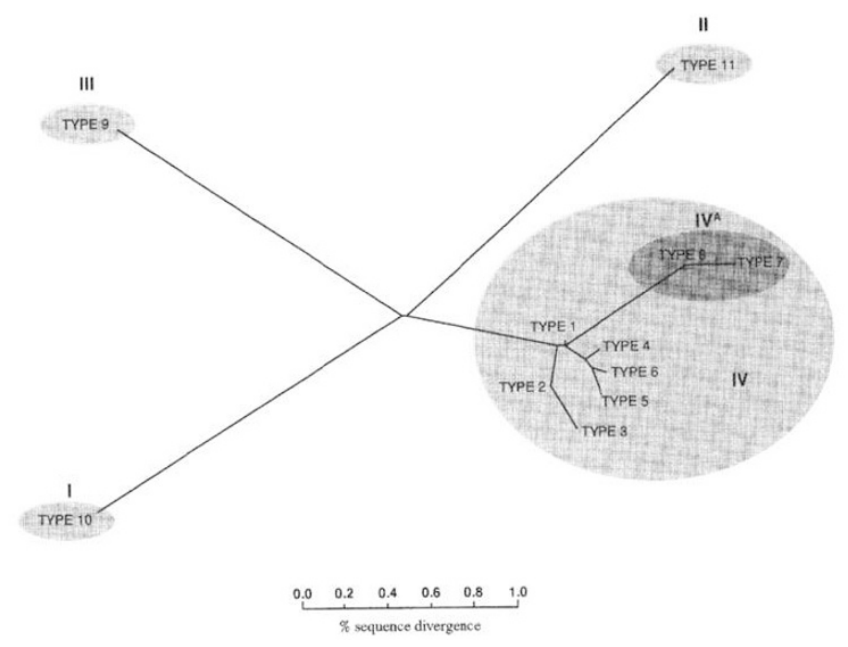

Fig. 3 FITCH phenogram clustering the distance matrix, based on restriction sites, of percentage sequence djvergence among $11 \mathrm{mtDNA}$ haplotypes as discribed in Table 3.

both Adriatic-Ionian and Ponto-Aegean zones, and apart from lineage III the remaining lineages are present at various levels in both zones.

\section{Population gene diversity}

The distance matrix of net interpopulation nucleotide divergence was used to construct a UPGMA tree (unweighted pair-group method using arithmetic averages) relating the 13 populations studied (Fig. 5). The populations clustered into five distinct clades (net nucleotide divergence between clades ranging

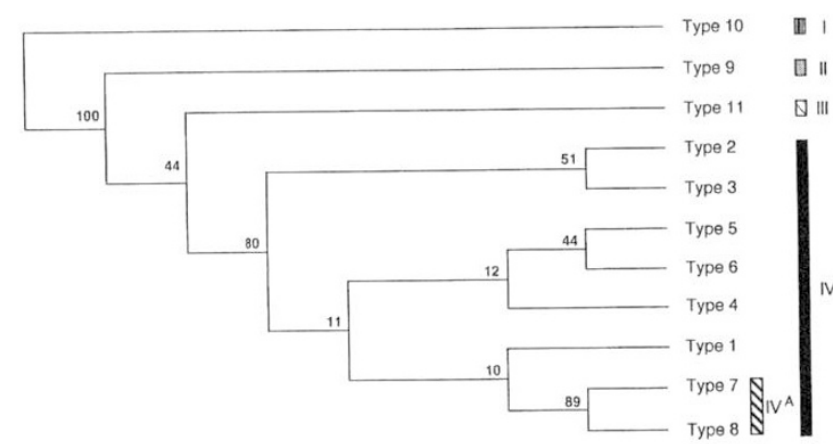

Fig. 4 Majority rule consensus tree clustering the 11 mtDNA haplotypes described in Table 3 . Their respective locations are as follows. Type 1: AC1, EVI, NES, TRI; Type 2: PRE; Type 3: ALF, THY; Type 4: OHR; Type 5: OHR; Type 6: TRI; Type 7: AC1, AC2, MOR, NES; Type 8: NES; Type 9: VEN; Type 10: GAR and Type 11: VOI, VEN. Numbers at the forks indicate the percentage of times the group consisting of the haplotypes located to the right of the fork occurred among the trees, out of 1000 trees. The tree was rooted with haplotype 10 . The principal mtDNA clades are indentified with vertical lines.

from 0.77 to 2.93 per cent), largely reflecting the racial partitioning of mtDNA phylogenetic groupings. These clusters include (Fig. 5): (A) Acheloos1 and 2, Mornos and Nestos populations; (B) Alfios, Thyamis, Ag. Germanos (Prespa), Evinos, Tripotamos and Ohrid populations; (C) only the population from Venetikos; (D) Voidomatis population; and (E) Garonne (Atlantic drainage population).

Statistically significant differences in haplotype frequencies among all populations were observed

(C) The Genetical Society of Great Britain, Heredity, 77, 608-618. 


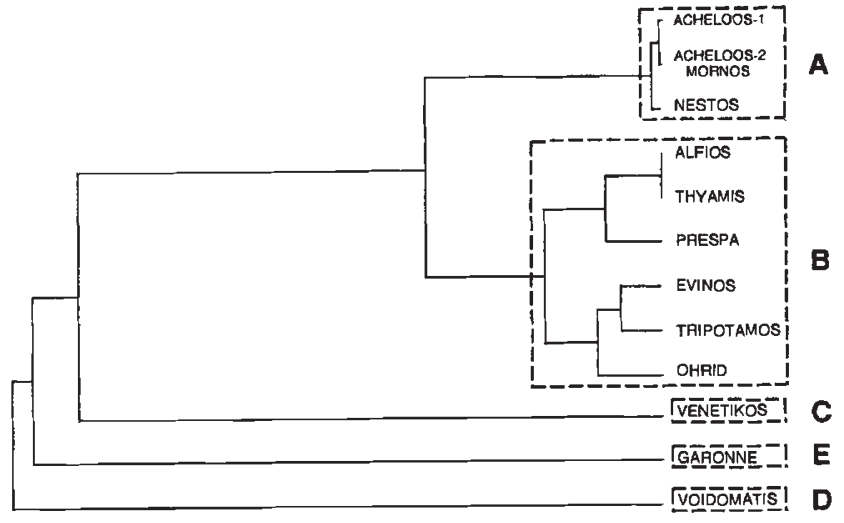

$$
\begin{array}{cccccc}
\mathbf{l} & 1 & 1 & 1 & 1 & \\
0.0 & 0.1 & 0.2 & 0.3 & 0.4 & 0.5 \\
\text { \% sequence divergence }
\end{array}
$$

Fig. 5 UPGMA phenogram clustering 13 Salmo trutta populations according to the distance matrix resulting from the maximum likelihood estimation of the net average number of nucleotide substitutions per site between populations (nucleotide divergence).

$\left(\chi_{120}^{2}=1927.2, P<0.001\right)$. The test for differences among the two ichthyogeographical zones (i.e. samples within zones had been pooled) resulted in a significant outcome $\left(\chi_{9}^{2}=163.05, P<0.001\right)$. Within the south Adriatic-Ionian zone and the PontoAegean zone significant differences among populations were also observed $\left(\chi_{48}^{2}=847.65, P<0.001\right.$ and $\chi_{10}^{2}=131.61, P<0.001$, respectively). Yet, significant substructuring was observed within cluster B $\left(\chi_{25}^{2}=432, \quad P<0.001\right)$, whereas the differences between the four populations in cluster $A$ were found to be nonsignificant $\left(\chi_{6}^{2}=12.35\right)$. As expected, pairwise tests among populations demonstrated significant differences between most; 71 out of 78 tests were found to differ significantly (data not shown). The UPGMA analysis of nucleotide divergence among populations (Fig. 5) also shows little geographical structure.

In contrast to the high interpopulation diversity observed (mean $=1.65 \pm 0.0002$ per cent), the intrapopulation diversity detected was zero or low (mean nucleotide diversity estimates $=0.063 \pm 0.0$ per cent). Thus, based on the $N_{\mathrm{ST}}$ estimate of 0.95 only 5 per cent of the overall genetic diversity observed was within populations as opposed to 95 per cent for among populations. The $N_{\mathrm{ST}}$ estimate found without the Atlantic population was similar (0.93). The Ohrid trout $(S$. t. letnica) did not cluster distinctively from $S$. trutta populations, although characterized by haplotypes 4 and 5 observed nowhere else.

\section{Discussion}

\section{Relationship among haplotypes and populations}

Despite the high levels of variation detected in the Control Region of higher vertebrates, D-loops of some fish species, including $S$. trutta appear to evolve at a lower rate than other regions of the mtDNA (Ferguson et al., 1995). This finding is further supported in our studies. The levels of divergence observed between the $11 \mathrm{mtDNA}$ genotypes studied here range from 0.21 to 3.42 per cent and are higher than the $0.16-1.92$ per cent observed in sequence analysis of D-loops (Bernatchez et al., 1992). Yet divergence values observed in a RFLP analysis of mtDNA between $S$. trutta and $S$. salar range from 6.18 to 6.52 per cent (Gyllensten \& Wilson, 1987).

The high level of haplotype differentiation observed indicates an extensive subdivision of the ancestral $S$. trutta group. The presence in the same geographical area of divergent mtDNA types is not a common observation and may suggest the existence of enough subsequent recolonization events with allopatrically evolved populations followed by limited natural intermixing (Avise et al., 1987). The sympatric occurrence of two well-defined mtDNA clades (haplotypes 9 with 11 and 1 with 7 in the drainages of Venetikos and Achellos1, respectively), where no stocking activities have been reported, is further evidence of admixture of clades evolved in allopatry. The five groups of haplotypes revealed by the FircH phenogram (Fig. 3) probably correspond to the five major phylogenetic groupings revealed by the analysis of mtDNA sequence variation among remote populations from western Europe to western Asia (Bernatchez et al., 1992; Giuffra et al., 1994; Bernatchez \& Osinov, 1995). Further sequence studies ongoing in our laboratory suggest that this is indeed the case (A. P. Apostolidis et al., unpublished data).

It has been established that brown trout represents one of the most highly genetically structured fish species studied to date (Bernatchez et al., 1992). However, the $N_{\mathrm{ST}}$ value of 0.95 observed between all brown trout populations is higher than that of 0.76 found by Bernatchez et al. (1992) and is higher, as far as we know, than any other estimates reported so far. Most of the populations examined had a unique profile without sharing common haplotypes with the other populations. This significant differentiation among the populations may result from a long time of isolation coupled with probable bottleneck and subsequent genetic drift phenomena. In such a case, common mtDNA genotypes among the populations 
may have become rare or extinct through stochastic lineage loss (Pamilo \& Nei, 1988).

The clustering of the Nestos population within group A (Fig. 5) can be interpreted in two ways. First, it reflects the repeated stocking with fish-farm stocks originating from the Acheloos river. In such a case, the presence of the common haplotypes is the result of stock transfers from the Acheloos river. Alternatively, it could be a common ancestral polymorphism in both geographically distant populations. Given the data presented it is difficult to distinguish between either of these two scenarios. However, if the first hypothesis is valid and the Nestos population is seriously affected by past stocking (not carried out since the 1970s) it is probably too late to 'restore' it using native breeders. Therefore careful consideration should be given to future initiatives aimed at introducing foreign fish stocks to local populations.

\section{Levels of congruence between nuclear gene and $m+D N A$ variation}

Results obtained from the analysis of mtDNA and allozyme variation showed that there are some points where the two methods are in agreement, such as the differentiation of the Garonne population (Atlantic drainage) from the Mediterranean populations. The importance of this dichotomy was also indicated by the magnitude of genetic distance values. In addition, both methods do not support the idea that the Ohrid population of $S$. $t$. letnica is a separate subspecies derived from an ancient common ancestor. Indeed the present results indicate a much more recent divergence. Also, both data sets indicate that the largest proportion of genetic variability of brown trout populations is distributed among and not within them.

Despite these similarities the general pattern of genetic relationships, as revealed by allozyme studies, appears not to correspond with those obtained from mtDNA data. The Mantel test, employing 10000 random permutations, showed that there is no correlation $(r)$ between the genetic distance matrices found with allozymes and mtDNA methods $(r=0.12, P=0.350)$. Furthermore, there was no correlation between the levels of intrapopulation diversity observed in the mitochondrial and nuclear genomes. Thus, no mtDNA diversity was found in two populations (Garonne and Voidomatis) which showed among the highest values of nuclear heterozygosity $(H=0.098$ and 0.046 , respectively; Karakousis \& Triantaphyllidis, 1990; Apostolidis et al., 1996). Reciprocally, mtDNA diversity was found in the population of Tripotamos $(h=0.15)$ where nuclear heterozygosity was zero $(H=0.0)$. Yet mtDNA data do not support the uniqueness of the population of Prespa which clustered within clade B (Fig. 5), in contrast with allozymes where it clustered separately.

Lack of congruence between mitochondrial and nuclear based phylogenies can result from the different modes of transmission and evolution of these genetic systems. Discrepancies between the two methodologies have frequently been reported in the literature (e.g. Ferguson et al., 1991; Bernatchez \& Osinov, 1995). The low intrapopulation mtDNA variability described here could be the result of bottleneck events. Indeed most populations examined live in small streams which are frequently subjected to periods of drought, substantially reducing the water level and consequently population size. Because the effective population size of mtDNA is a quarter that of nuclear DNA, similar type population bottlenecks could reduce mitochondrial variability without significantly affecting nuclear variability. The occurrence of population bottlenecks is consistent with the reduced allozyme diversity observed in some populations (Apostolidis et al., 1996). Finally, the results reinforce the need to examine multiple genetic systems when inferring phylogenies from molecular data.

\section{Divergence times of brown trout phylogenetic groups and relation with paleogeographical events}

The application of a molecular clock for estimating times of divergence among phylogenetic assemblages requires several assumptions (Nei, 1987) which may not always hold true. However, if there is no important deviation from this model, crude estimates of the separation time among populations or groups of populations can be given. If the substitution rate of $0.5-0.9$ per cent per million years which has been estimated in salmon from RFLP analysis of mtDNA (Martin \& Palumbi, 1993) is used, we can estimate the divergence time between the five phylogenetic groups described above. Hence, the divergence time between groups I, II, III and IV (Figs 3 and 4), based on mtDNA data would be between 2.7 and 6.8 MYBP (million years before present). During the Middle Miocene, in South Eurasia there were two principal inner basins: the Mediterranean and the Paratethys which included the Black Sea, Caspian and Aral (Bianco, 1990). At this time two main geological events occurred: first the isolation of the Mediterranean sea from the Atlantic Ocean, while the connections between the Mediterranean 
and the Paratethys were also interrupted (both mtDNA and allozyme data suggest that the isolation of Atlantic from Mediterranean brown trout populations occurred during this time) and secondly, at the end of the Messinian both the Mediterranean and the Paratethys were reduced to a network of lakes (Hsu, 1978). This event is termed the 'Lago Mare' phase of the Mediterranean. The 'Lago Mare' stage surely played an essential role in the isolation of Mediterranean brown trout populations and in a later dispersion in peri-Mediterranean river systems. It seems probable that the isolation among the three main lineages of Mediterranean brown trout (II, III and IV) happened during this time. The closer relationship between group IV and group IV $^{\mathrm{A}}$ suggests that these two groups became isolated more recently, their time of separation estimated at 0.75 to 1.35 MYBP (Pleistocene).

The considerable geographical distribution of group IV could indicate that this represents the founder population in the area whereas the other groups have resulted from subsequent recolonization events. However, given the paucity of historical and archaeological information it is difficult to determine the exact sequence of events and therefore the geographical origin of the other phylogenetic groups. Further analysis of fish populations from various locations will be necessary to determine the origins and genetic relationships among these groups and to verify the level of introgressive hybridization between phylogenetic assemblages.

\section{Acknowledgements}

The authors thank Dr P. Berrebi for providing samples; Dr M. Hansen for his willing assistance; Prof. P. S. Economidis and Dr A. Kouvatsi for their fruitful discussions; $\mathrm{Dr} \mathrm{R}$. Loftus for his valuable advice and his friendly cooperation, Dr S. Tchahalidis and $\mathrm{Mr} \mathrm{N}$. Nicolaidis and A. Triantafylidis for their help in the present study. Financial support from the European Commission within the framework EV5VCT920097 project is gratefully acknowledged.

\section{References}

APOSTOLIDIS, A. P., KARAKOUSIS, Y. AND TRIANTAPHYLLIDIS C. 1996. Genetic divergence and phylogenetic relationships among brown trout (Salmo trutta L.) populations from Greece and other European countries. Heredity, 76, 551-560.

AVISE, J. C. 1994. Molecular Markers, Natural History and Evolution. Chapman and Hall, New York.
AVISE, J. C., ARNOLD, J., BALl, R. M., BERMinghaM, E., LAMP, T., NEIGEL, J. E. ET AL. 1987. Intraspecific phylogeography: the mitochondrial DNA bridge between population genetics and systematics. Ann. Rev. Ecol. Syst., 18, 489-522.

BEMBo, D. G., Weightman, A. J., BEVERTON, R. J. AND CRESSWELL, R. C. 1994. Mitochondrial DNA variation in River Usk brown trout, Salmo trutta. J. Fish Biol., 44, 717-723.

BERNATCHEZ, L. AND OSINOV, A. 1995. Genetic diversity of trout (genus Salmo) from its most eastern native range based on mitochondrial DNA and nuclear gene variation. Mol. Ecol, , 4, 285-297.

BERNATCHEZ, L., SAVARD, L., DODSON, J. AND PALLOTA, D. 1988. Mitochondrial DNA sequence heterogeneity among James-Hudson Bay anadromous coregonines. Finnish Fish. Res., 9, 17-26.

BERNATCHEZ, L., GUYOMARD, R. AND BONHOMME, F. 1992. DNA sequence variation of the mitochondrial control region among geographically and morphologically remote European brown trout Salmo trutta populations. Mol. Ecol., 1, 161-173.

B1ANCO, P. G. 1990. Potential role of the palaeohistory of the Mediterranean and Paratethys basins on the early dispersal of Euro-Mediterranean freshwater fishes. Ichthyol. Explor. Freshwaters, 1, 167-184.

CRONIN, M. A., SPEARMAN, W. J., WILMOT, R. L., PATTON, J. C. AND BICKHAM, J. W. 1993. Mitochondrial DNA variation in Chinook (Oncorhynchus tshawytscha) and chum salmon $(O$. keta) detected by restriction enzyme analysis of polymerase chain reaction (PCR) products. Can. J. Fish. Aquat. Sci., 50, 708-715.

ESTOUP, A., PRESA, P., KRIEG, F., VAIMAN, D. AND GUYOMARD, R. 1993. (CT $)_{\mathrm{n}}$ and $(\mathrm{GT})_{\mathrm{n}}$ microsatellites: a new class of genetic markers for Salmo trutta L. (brown trout). Heredity, 71, 488-496.

FELSENSTEIN, J. 1992. PHYLIP (Phylogeny inference package) version 3.4. Department of Genetics, SK-50, University of Washington, Seattle, WA.

FERGUSON, A. 1989. Genetic differences among brown trout, Salmo trutta, stocks and their importance for the conservation and management of the species. Freshwater Biol., 21, 35-46.

FERGUSON, M. M., DANZMANN, R. G. AND HUTCHINGS, J. A. 1991. Incongruent estimates of population differentiation among brook charr, Salvelinus fontinalis, from Cape Race, Newfoundland, Canada, based upon allozyme and mitochondrial DNA variation. J. Fish Biol., 39 (Suppl. A), 79-85.

FERGUSON, A., TAGGART, J. B., PRODOHL, P. A., McMEEL, O., THOMPSON, C., STONE, C. ET AL. 1995. The application of molecular markers to the study and conservation of fish populations, with special reference to Salmo. J. Fish Biology, 47 (Suppl. A), 103-126.

Fitch, W. M. AND MARGOliash, E. 1967. Construction of phylogenetic trees. Science, 155, 279-284.

GIUFFRA, E., BERNATCHEZ, L. AND GUYOMARD, R. 1994. Mitochondrial control region and protein coding genes 
sequence variation among phenotypic forms of brown trout Salmo trutta from northern Italy. Mol. Ecol., 3, 161-172.

GYlLENSTEN, U. AND Wilson, A. C. 1987. Mitochondrial DNA of salmonids: Inter- and intraspecific variability detected with restriction enzymes. In: Ryman, N. and Utter, F., (eds) Population Genetics and Fishery Management, pp. 301-317. University of Washington Press, Seattle.

HALL, H. J. AND NAWROCK1, L. W. 1995. A rapid method for detecting mitochondrial DNA variation in the brown trout, Salmo trutta. J. Fish Biol., 46, 360-364.

HSU, K. J. 1978. When the Black Sea was drained. Sci. Am., 238 (4), 52-63.

HYNES, R. A., DUKE, E. J. AND JOYCE, P. 1989. Mitochondrial DNA as a genetic marker for brown trout, Salmo trutta L., populations. J. Fish Biol., 35, 687-701.

KARAKOUSIS, Y. AND TRIANTAPHYLLIDIS, C. 1990. Genetic structure and differentiation among Greek brown trout (Salmo trutta L.) populations. Heredity, 64, 297-304.

KOCHER, T. D., THOMAS, W. K., MEYER, A., EDWARDS, S. V., PAABO, S., VILlablanCA, F. X. AND WILSON, A. C. 1989. Dynamics of mitochondrial DNA evolution in animals: amplification and sequencing with conserved primers. Proc. Natl. Acad. Sci. U.S.A., 86, 6196-6200.

KRIEG, F. AND GUYOMARD, R. 1985. Population genetics of French brown trout (Salmo trutta L.): large geographical differentiation of wild populations and high similarity of domesticated stocks. Génét. Sél. Évol., 17, 225-242.

LYNCH, M. AND CREASE, T. J. 1990. The analysis of popula- tion survey data on DNA sequence variation. Mol. Biol. Evol., 7, 377-394.

MANTEL, N. A. 1967. The detection of disease clustering and a generalised regression approach. Cancer Res., 27, 209-220.

MARTIN, A. P. AND PALUMBI, S. R. 1993. Body size, metabolic rate, generation time, and the molecular clock. Proc. Natl. Acad. Sci. U.S.A., 90, 4087-4091.

MCELROY, D., MORAN, P., BERMINGHAM, E. AND KORNFIELD, J. 1991. REAP: The Restriction Enzyme Analysis Package, Version 4.0. University of Maine, Orono, ME. McVEIGH, H. P., BARTLETT, S. E. AND DAVIDSON, W. S. 1991. Polymerase chain reaction/direct sequence analysis of the cytochrome b gene in Salmo salar. Aquaculture, 95, 225-233.

NE1, M. 1987. Molecular Evolutionary Genetics. Columbia University Press, New York.

PAMILO, P. AND NEI, M. 1988. Relationships between gene trees and species trees. Mol. Biol. Evol., 5, 568-583.

PRODÖHL, P. A., TAGGART, J. B. AND FERGUSON, A. 1992. Genetic variability within and among sympatric brown trout (Salmo trutta) populations: multi-locus DNA fingerprint analysis. Hereditas, 117, 45-50.

ROFF, D. A. AND BENTZEN, P. 1989. The statistical analysis of mitochondrial DNA polymorphisms: $\chi^{2}$ and the problem of small samples. Mol. Biol. Evol., 6, 539-545.

ROHLF, F. J. 1990. NTSYS-pc. Numerical Taxonomy and Multivariate Analysis System. Exeter Software, New York.

TAGGART, J. B. AND FERGUSON, A. 1990. Hypervariable minisatellite DNA single locus probes for the Atlantic salmon, Salmo salar L. J. Fish Biol., 37, 991-993. 